\title{
Passage rate and total clearance rate from the rumen of cows fed on grass silages differing in cell-wall content
}

\author{
BY MARLOU W. BOSCH', AND MARIANNE BRUINING \\ ${ }^{1}$ Department of Animal Nutrition, Agricultural University, Haagsteeg 4, NL 6708 PM Wageningen, \\ The Netherlands \\ ${ }^{2}$ Department of Human and Animal Physiology, Agricultural University, Haarweg 10, \\ NL 6709 PJ Wageningen, The Netherlands
}

(Received 19 May 1992 - Revised 1 June 1994 - Accepted 7 June 1994)

\begin{abstract}
Four non-lactating, rumen-fistulated cows were fed ad lib. on two grass silages (first cut (FC) and second cut (SC)) harvested at different growth stages, resulting in different crude-protein (CP) and neutraldetergent-fibre (NDF) contents (FC, $152 \mathrm{~g} \mathrm{CP} / \mathrm{kg}, 515 \mathrm{~g} \mathrm{NDF} / \mathrm{kg}$ and $\mathrm{SC}, 210 \mathrm{~g} \mathrm{CP} / \mathrm{kg}$, $442 \mathrm{~g} \mathrm{NDF} / \mathrm{kg}$ ). Voluntary intake and rumen contents, total as well as organic matter were higher for silage FC. Fractional passage rate from the rumen, calculated from the logarithmic decline in Cr-NDF rumen pool, was higher for silage FC $(0.0395 / \mathrm{h}$ and $0.0446 / \mathrm{h}$ for silages $\mathrm{SC}$ and $\mathrm{FC}$ respectively). When fractional passage rates from the rumen were calculated by dividing the intake of indigestible organic matter by the mean rumen pool of this fraction, the same differences between silages were found, although the actual levels were much lower $(0.0258 / \mathrm{h}$ and $0.0300 / \mathrm{h}$ for silages $\mathrm{SC}$ and $\mathrm{FC}$ respectively). The results from the present experiment suggest that disappearance rate from the rumen of particles with a size between 1.25 and $0.071 \mathrm{~mm}$ is the rate-limiting step in the control of rumen fill.
\end{abstract}

Rumen: Digesta kinetics: Silage

Nutrient supply and, as a result, production in dairy cows is influenced by the capacity of the rumen to clear the ingested feed (rumen contents $\times$ clearance rate). The ingested feed can be cleared from the rumen either by microbial degradation or by passage to the lower gut. The rate of clearance of rumen contents has been shown to depend on the chemical and physical composition of the feedstuff, the rate of microbial degradation, particle size and $\mathrm{pH}$ in the rumen (Sutherland, 1987).

The rate of passage of undegraded feed particles from the rumen to the lower gut has been estimated using the external marker Cr-neutral-detergent fibre (Cr-NDF). However, it is not clear which rumen pool is represented by $\mathrm{Cr}-\mathrm{NDF}$ or whether differences between diets can be measured using Cr-NDF. Robinson et al. (1987) and Bosch et al. $(1988,1992)$ suggest that the hourly fractional rate of rumen passage $\left(k_{\mathrm{p}}\right)$, as calculated from the $\mathrm{Cr}-\mathrm{NDF}$ faecal concentration curve, is likely to overestimate ruminal passage as a fraction of total rumen contents.

Bruining \& Bosch (1992) found that particle size of the Cr-NDF has a great influence on the calculated fractional passage rate from the rumen.

The probability of feed particles escaping from the rumen is inversely related to particle size (Poppi et al. 1980), but passage rate from the rumen of the smallest particles is still lower than that of the fluid (Faichney, 1986; Bruining \& Bosch, 1992). Particles with a size above the critical particle size, defined by Kennedy \& Poppi (1984) as the sieve aperture retaining the top $5 \%$ of faecal particulate dry matter $(1.18 \mathrm{~mm}$ for cattle), have a low 
probability of leaving the rumen. Degradation and passage are usually expressed as fractional rate constants and therefore rumen pool sizes, from which such fractional rate constants are derived, may be equally important.

We report an experiment with non-lactating cows, fed on grass silages differing in quality due to harvesting at different stages of growth. The objectives of the experiment were to determine: (1) how the weight of rumen contents is influenced by silage quality; (2) how the kinetics of particles leaving the rumen are influenced by silage quality; (3) whether the rate of decrease in particle size limits the total weight of rumen contents and (4) whether $\mathrm{Cr}-\mathrm{NDF}$ is a reliable marker for measuring passage rate from the rumen.

\section{MATERIALS AND METHODS}

\section{Animals and diets}

Four rumen-fistulated non-lactating cows were used in this experiment. In a crossover design the cows were fed ad lib. on two wilted grass silages. The two grass silages, from the same field (first cut (FC) and second cut (SC)), were harvested at different growth stages, resulting in different cell-wall and crude-protein $(\mathrm{CP}, \mathrm{N} \times 6.25)$ contents. The $\mathrm{FC}$ was harvested at a NDF content of $515 \mathrm{~g} / \mathrm{kg}$ dry matter (DM) and a CP content of $152 \mathrm{~g} / \mathrm{kg} \mathrm{DM}$. After a regrowth period of approximately 6 weeks, the $\mathrm{SC}$ was harvested at a NDF content of $442 \mathrm{~g} / \mathrm{kg} \mathrm{DM}$ and a CP content of $210 \mathrm{~g} / \mathrm{kg} \mathrm{DM}$. The chemical compositions of the two silages, the harvesting dates and the soluble and indigestible organic matter fractions are given in Table 1. Both silages had a field wilting period of $2 \mathrm{~d}$ (between cutting and ensiling).

The cows were offered feed twice daily, at 07.00 and 19.00 hours. Feed refusals were removed at 09.00 and 07.00 hours. During the day (from 09.00 to 19.00 hours) the animals had no access to the feeds. Feed intake was recorded daily, and was corrected for the ash content in the refusals to calculate daily organic matter (OM) intake.

\section{Experimental procedure}

The experiment consisted of a measurement period of 2 weeks on each diet, preceded by diet adaptation periods of 3 weeks. In the first week of the experimental period the passage rate of Cr-NDF particles and outflow rate of cobalt-ethylene diaminotetra acetate (CoEDTA) were measured in faecal samples. In the second week rumen evacuations were carried out to measure passage rate of $\mathrm{Cr}-\mathrm{NDF}$ particles directly from the rumen.

\section{Rate-of-passage measurements}

On day 1 of the first week, at 06.00 hours, $100 \mathrm{~g} \mathrm{Cr}-\mathrm{NDF}(0 \cdot 2-1.0 \mathrm{~mm}$, approximately $50 \mathrm{~g} \mathrm{Cr} / \mathrm{kg}$ ) and $30 \mathrm{~g}$ Co-EDTA (approximately $148 \mathrm{~g} \mathrm{Co} / \mathrm{kg}$ ) were added to the rumen contents (through the cannula) as markers for passage rates of the particulate $\left(k_{\mathrm{p}}\right)$ and liquid $\left(k_{1}\right)$ phases from the rumen respectively. Both markers were prepared as described by Uden et al. (1980). Samples of rumen fluid were taken on day 1 at 05.45 hours and every hour from 09.00 until 20.00 hours and analysed for Co. Faeces were collected and sampled every $2 \mathrm{~h}$ on days 2,3 and 4 from 08.00 till 18.00 hours. Faecal samples were dried at $70^{\circ}$, ground at $1 \mathrm{~mm}$ and analysed for $\mathrm{DM}, \mathrm{Cr}$ and $\mathrm{Co}$. In the second week of the experimental period, on day 1 at 06.00 hours, $300 \mathrm{~g} \mathrm{Cr}-\mathrm{NDF}$ was injected into the rumen. The amount of $\mathrm{Cr}-\mathrm{NDF}$ given was increased to be able to measure $\mathrm{Cr}$ concentration accurately in the rumen contents over $5 \mathrm{~d}$. Rumen evacuations were performed twice daily on days $1-4$, once in the morning at $09.30,10.30,11.30$ or 12.30 hours and once in the afternoon at 14.30 , $15.30,16.30$ or 17.30 hours in repeated sequences, and on day 5 between 07.00 and 08.00 hours without feeding the animals the night before. 
Table 1. Chemical composition ( $\mathrm{g} / \mathrm{kg}$ dry matter), soluble and indigestible organic matter $(O M)$ fractions $(\mathrm{g} / \mathrm{kg}$ dry matter) and harvesting dates of two grass silages

\begin{tabular}{lcc}
\hline & \multicolumn{2}{c}{ Silage } \\
\cline { 2 - 3 } & First cut & Second cut \\
\hline Dry matter $(\mathrm{g} / \mathrm{kg})$ & 620 & 560 \\
OM & 900 & 889 \\
Crude protein & 152 & 210 \\
Neutral-detergent fibre & 515 & 442 \\
Acid-detergent fibre (ADF) & 280 & 250 \\
Acid-detergent lignin & 28 & 22 \\
Indigestible ADF & 65 & 49 \\
Soluble OM fraction & 222 & 280 \\
Undegradable OM fraction & 150 & 124 \\
Harvesting date & 13 Jun 1988 & 1 Aug 1988 \\
\hline
\end{tabular}

Rumen evacuations were performed according to the procedure described by Robinson et al. (1987). Rumen contents were weighed, thoroughly mixed and at least fifteen small samples were taken during mixing by hand to obtain representative samples. Rumen contents were returned immediately after sampling. A $10 \mathrm{~g} / \mathrm{kg}$ sample of the total weight was dried at $70^{\circ}$, ground and analysed for DM, ash and $\mathrm{Cr}$, and two $20 \mathrm{~g} / \mathrm{kg}$ samples were stored at $-20^{\circ}$ until wet sieve analysis

\section{Calculations of rumen kinetics}

Assuming that rates of particle passage follow first-order kinetics, the fractional outflow rate of rumen fluid was calculated from the logarithmic decline in Co concentration in the rumen fluid ( $k_{1}$-Co-rumen) as well as from the descending part of the faecal concentration curve of $\mathrm{Co}\left(k_{1}-\mathrm{Co}\right.$-faeces). The descending parts of the faecal concentration curves of $\mathrm{Cr}$ were used, under the same assumptions, to calculate the fractional particle passage rate $\left(k_{\mathrm{p}^{-}}\right.$ Cr-faeces).

The total clearance rate of $\mathrm{OM}$ from the rumen, equal to the sum of passage rate plus degradation rate $\left(k_{\mathrm{c}}-\mathrm{OM}\right)$, as well as the firactional outflow rate of $\mathrm{Cr}-\mathrm{NDF}$-particles from the rumen $\left(k_{\mathrm{p}}-\mathrm{Cr}\right.$-rumen) were estimated from the logarithmic decline in the different pool sizes with time after feeding.

At steady state the amount of material entering the rumen in a certain time is equal to the amount cleared during that time. When intake as well as the average rumen pool size are known, the fractional clearance rates of material disappearing from the rumen can be calculated by the intake expressed as a fraction of total rumen pool size. Fractional passage rates of the indigestible $\mathrm{OM}\left(k_{\mathrm{p}}-\mathrm{iOM}\right)$ and of the indigestible acid-detergent fibre (iADF) $\left(k_{\mathrm{p}}\right.$-iADF) from the rumen were calculated by dividing the intake of iOM or iADF by the mean rumen pool of these fractions. Mean rumen pool size of these fractions was calculated from the logarithmic decline in pool sizes, using the samples taken $0.5,3.5$ and $8.5 \mathrm{~h}$ after feeding:

$$
\text { mean rumen pool size }=1 / 10 \times \int_{0}^{10} V_{0} \times \mathrm{e}^{-k c t} \mathrm{~d} t,
$$

where $V_{0}$ is calculated rumen pool at $t=0$, and $k_{\mathrm{c}}$ is calculated rate of passage (slope of logarithmic decline in pool size with time). 
Because iADF can only disappear from the rumen by passage, the fractional passage rate of the small-particle pool was calculated from the logarithmic decline in iADF in the smallparticle pool ( $k_{\mathrm{p}}$-iADF-SP), corrected for the iADF entering the small-particle pool from large particles through particle size reduction.

Rumen pool sizes were corrected for the Cr-NDF, assuming that all $\mathrm{Cr}-\mathrm{NDF}$ was in the iADF fraction in particles with a size between 1.25 and $0.071 \mathrm{~mm}$. The $\mathrm{Cr}-\mathrm{NDF}$ particles, which have an initial size of $0 \cdot 1-2 \cdot 0 \mathrm{~mm}$, are not degraded, and it was assumed that breakdown through rumination was negligible.

\section{Particle size analysis}

Particle size distributions of rumen samples of the $09.30,12.30$ and 17.30 hours (i.e. $0 \cdot 5,3 \cdot 5$ and $8.5 \mathrm{~h}$ after feeding) and the 'day 5 ' morning evacuations, were determined by wet sieving of about $50 \mathrm{~g}$ wet rumen contents in a 'Fritsch Analysette 3' (Fritsch GMBH, 6580 Idar-Oberstein, Germany) for $30 \mathrm{~min}$, using the method described by Bosch et al. (1992). Three sieve-pore sizes were used: $5,1.25$ and $0.071 \mathrm{~mm}$.

The DM fractions retained on the sieves were determined, and the DM fraction passing the $0.071 \mathrm{~mm}$ sieve was calculated by difference. Rumen contents were divided into two pools, a large-particle (LP) pool (DM retained on the 5 and the $1.25 \mathrm{~mm}$ sieves), and a small-particle (SP) pool (DM passing the $1.25 \mathrm{~mm}$ sieve, i.e. DM retained on the $0.071 \mathrm{~mm}$ sieve plus DM passing the $0.071 \mathrm{~mm}$ sieve). Acid-detergent fibre (ADF) and iADF composition was determined in the LP, the particles retained on the $0.071 \mathrm{~mm}$ sieve and the total rumen contents of the same evacuations.

\section{Analysis of soluble and undegradable OM fractions}

Samples of about $70 \mathrm{~g}$ total rumen contents of the $09.30,12.30$ and 17.30 hours, and of the day 5 morning evacuations were weighed into nylon bags (Nybolt, Zürich, Switzerland) of $90 \times 180 \mathrm{~mm}$ with a pore size of $41 \mu \mathrm{m}$ (eight bags per rumen sample), and washed in a washing machine (Intimat de Luxe, Zanker, Neurenberg, Germany) twice with cold water (10-15 , approximately $45 \mathrm{~min} /$ wash) using the wool program. The soluble fraction was determined as the OM loss from the bags. The iOM fraction was determined in the same rumen contents analysed for the soluble fraction, as well as the corresponding LP fraction, by the OM loss after incubation in eight nylon bags per sample in the rumen for $336 \mathrm{~h}$ (in the same cows, fed with the silages used in the present experiment), and washing afterwards in the washing machine twice with cold water as described above. The soluble and undegradable OM fractions of samples of the two silages were also determined by the same method. The iOM fractions in the rumen samples were used to calculate intake and rumen pools of iOM.

\section{Chemical analyses}

DM was determined by drying to constant weight at $103^{\circ}$ and ash was determined in an oven at $550^{\circ}$. $\mathrm{N}$ was determined by the $\mathrm{Kjeldahl}$ method with $\mathrm{K}_{2} \mathrm{SO}_{4}$ and $\mathrm{HgO}$ as catalysts. ADF was measured according to the method described by Goering \& Van Soest (1970), and iADF according to the method described by Penning \& Johnson (1983). Co concentration in the rumen fluid was determined using the standard addition method, with an atomic absorption spectrophotometer (SpectrAA-300; Varian, Mulgrave, Australia), at a wavelength of $240.7 \mathrm{~nm}$ (Varian, 1987). Marker concentrations in dried faeces (Cr and $\mathrm{Co}$ ) and dried rumen contents $(\mathrm{Cr})$ were determined by atomic absorption at wavelengths of 357.9 (Cr) and $240.7 \mathrm{~nm}(\mathrm{Co})$ using the concentration method after wet destruction (Uden et al. 1980). 


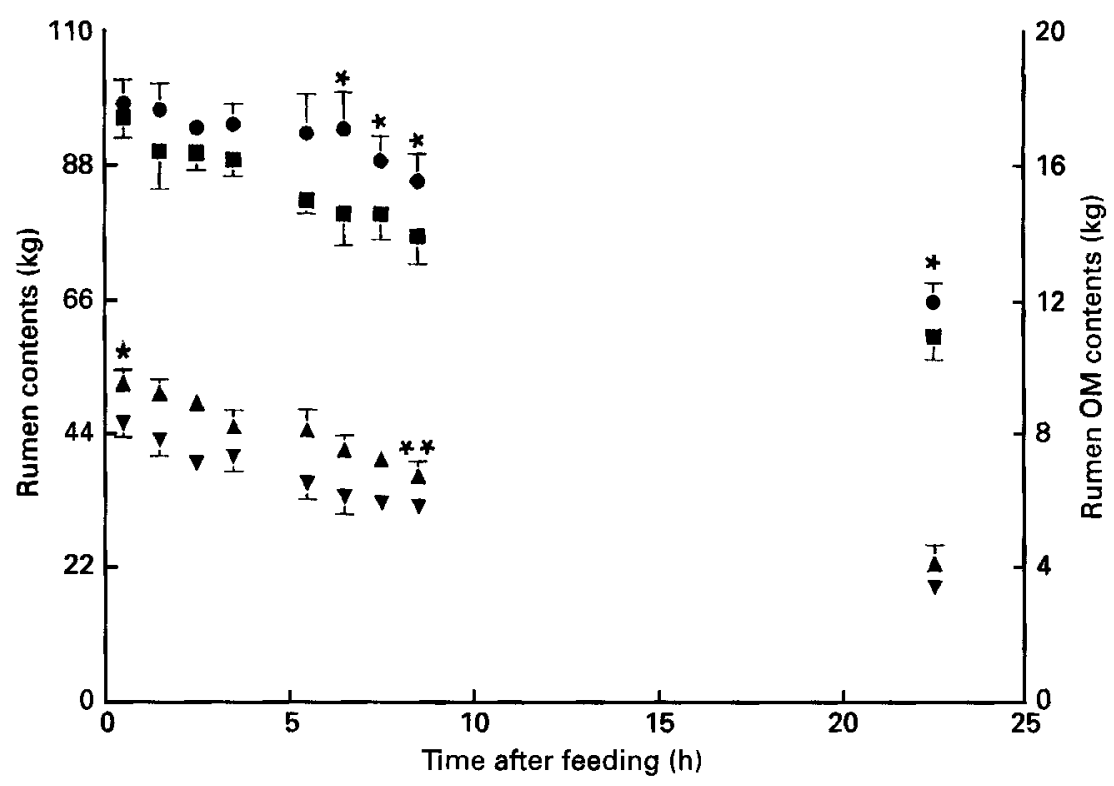

Fig. 1. Total rumen contents $(\mathrm{kg})$ and rumen organic matter $(\mathrm{OM})$ contents $(\mathrm{kg})$, at different times after feeding, in cows fed on two grass silages, first cut (FC) and second cut (SC). Values are means for four cows, with their standard errors indicated by vertical bars. (O), FC, total; (ם), SC, total; (A), FC, OM; (V), SC, OM. Mean values were significantly different between silages: ${ }^{*} P<0.05,{ }^{*} P<0.01$. For details, see pp. $42-43$.

\section{Statistical analyses}

Data were analysed statistically using the ANOVA procedure of the SPSSPC + statistical package (SPSS Inc., 1988).

\section{RESULTS}

Intake was higher $(P<0.01)$ for FC than for SC $(10 \cdot 1$ (SE 0.4) and 9.1 (sE 0.2) $\mathrm{kg} \mathrm{OM} / \mathrm{d}$ respectively). For silage $\mathrm{SC}$ the soluble $\mathrm{OM}$ fraction was $280 \mathrm{~g} / \mathrm{kg}$ and for silage $\mathrm{FC}$, $222 \mathrm{~g} / \mathrm{kg}$. The iOM fractions were 124 and $150 \mathrm{~g} / \mathrm{kg}$ for silages SC and FC respectively.

Rumen contents, total as well as OM, were at all times higher for silage FC (Fig. 1). However, the differences in total rumen contents were only significant $(P<0.05)$ after more than $6 \mathrm{~h}$ following feeding. Significant differences in OM content in the rumen between the silages were only found at 0.5 and $8.5 \mathrm{~h}$ after feeding.

The distribution of rumen particle sizes at different times after feeding is given in Fig. 2 for silages FC and SC respectively. Though not significant, the amount (kg DM) of LP $(>1.25 \mathrm{~mm})$, and the amount of SP $(<1.25 \mathrm{~mm})$, were at all times higher for FC than for SC. However, within the SP pool the fraction of DM passing the $0.071 \mathrm{~mm}$ sieve was higher for SC.

The $\mathrm{iADF}$ : ADF ratio in rumen digesta $(0 \cdot 29-0-47)$ was considerably higher than in the silages $(0 \cdot 20)$ and increased for all rumen pools, except the $<0.071 \mathrm{~mm}$ pool, with time after feeding. With decreasing particle size the iADF:ADF ratio increased.

Fractional passage rates from the rumen of liquid and particulate phases, derived from the descending parts of the faecal concentration curves as well as measured directly in the rumen, are given in Table 2. For all marker log plots a linear relationship was found ( $r$ 0.95-0.99). There were no differences between silages in passage rate of the liquid phase. The $k_{1}$-Co-rumen was significantly higher $(P<0.001)$ than the $k_{1}$-Co-faeces. The passage 


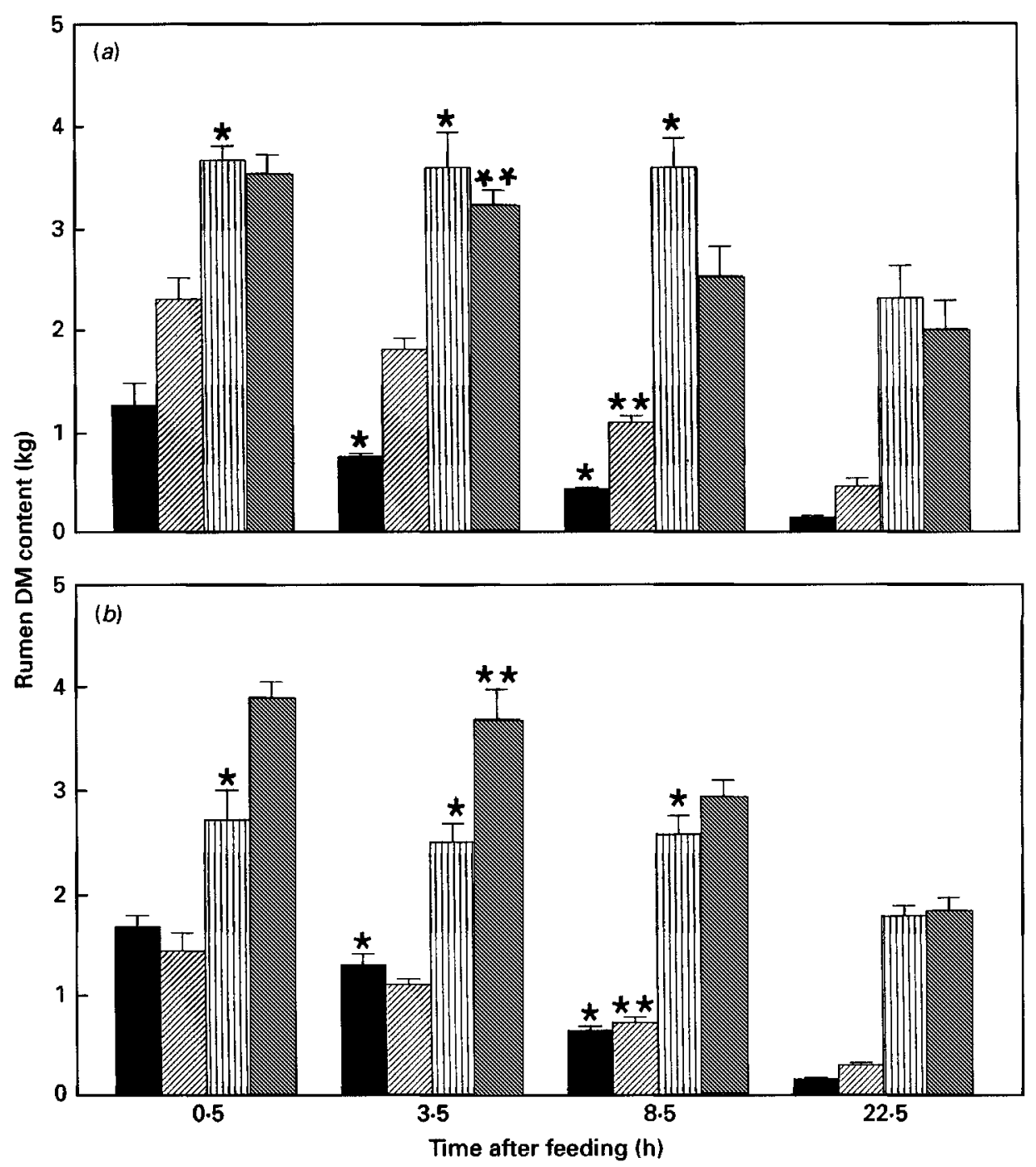

Fig. 2. Dry matter (DM) contents of different particle pools in the rumen of cows fed on (a) first cut silage and (b) second cut silage, measured at $0.5,3.5,8.5$ and $22.5 \mathrm{~h}$ after feeding. Particle sizes: (D), $>5 \mathrm{~mm}$; $(\square)$, $1.25-5 \mathrm{~mm}$; (四), 0.071-1.25 mm; (罝), <0.071 mm. Values are means for four cows, with their standard errors represented by vertical bars. Mean values were significantly different between silages: ${ }^{*} P<0 \cdot 05,{ }^{*} P<0 \cdot 01$. For details, see pp. $42-44$.

rate of the Cr-NDF was higher $(P<0.05)$ for $\mathrm{FC}$ than for SC when measured directly in the rumen $\left(k_{\mathrm{p}}-\mathrm{Cr}\right.$-rumen), but was not significantly different between silages when calculated from the faecal concentration curves $\left(k_{\mathrm{p}}-\mathrm{Cr}\right.$-faeces $)$. The $k_{\mathrm{p}}-\mathrm{Cr}$, like the $k_{\mathrm{l}}-\mathrm{Co}$, was significantly higher when measured directly in the rumen than when calculated from the faecal concentration curves $(P<0.001)$. Passage rates of iOM $\left(k_{\mathrm{p}}\right.$-iOM, $\left.P=0.02\right)$ and of iADF $\left(k_{\mathrm{p}}\right.$-iADF, $\left.P=0.06\right)$ were higher for FC than for SC. Within silages, both were lower than $k_{\mathrm{p}}$-Cr-rumen $(P<0 \cdot 001)$, and $k_{\mathrm{p}}$-iOM was lower than $k_{\mathrm{p}}$-iADF $(P<0.01)$. However, there was a significant correlation between $k_{\mathrm{p}}-\mathrm{Cr}$-rumen and $k_{\mathrm{p}}$-iOM $\left(k_{\mathrm{p}}-\mathrm{Cr}=\right.$ $0.0025+1.4177 \times k_{\mathrm{p}}$-iOM, $\left.r 0.98, P<0.001\right)$. On average, $k_{\mathrm{p}}-\mathrm{Cr}$-rumen was not significantly 
Table 2. Hourly fractional passage rates $(k)$ from the rumen of liquid $(l)$ and particulate ( $p$ ) phases (measured in the faeces or directly in the rumen), indigestible organic matter $(i O M)$, indigestible acid-detergent fibre (iADF) and small particles $(S P)$, and the hourly fractional clearance rate of organic matter $\left(\mathrm{k}_{c}-O M\right)$ from the rumen of cows fed on two grass silages $\dagger$

(Mean values with their pooled standard errors for four cows)

\begin{tabular}{|c|c|c|c|c|}
\hline & \multicolumn{2}{|c|}{ Silage } & \multirow[b]{2}{*}{ SEM } & \multirow{2}{*}{$\begin{array}{c}\text { Statistical } \\
\text { significance }\end{array}$} \\
\hline & First cut & Second cut & & \\
\hline $\begin{array}{l}k_{\mathrm{1}}-\mathrm{Co} \text {-faeces } \\
k_{\mathrm{p}}-\mathrm{Cr} \text {-faeces }\end{array}$ & $\begin{array}{l}0.0630 \\
0.0330\end{array}$ & $\begin{array}{l}0.0610 \\
0.0303\end{array}$ & $\begin{array}{l}0.0026 \\
0.0046\end{array}$ & $\begin{array}{l}\text { NS } \\
\text { NS }\end{array}$ \\
\hline $\begin{array}{l}k_{\mathrm{1}} \text {-Co-rumen } \\
k_{\mathrm{p}}-\mathrm{Cr} \text {-rumen }\end{array}$ & $\begin{array}{l}0 \cdot 1232 \\
0 \cdot 0446\end{array}$ & $\begin{array}{l}0.1120 \\
0.0395\end{array}$ & $\begin{array}{l}0.0251 \\
0.0042\end{array}$ & $\underset{*}{\text { NS }}$ \\
\hline $\begin{array}{l}k_{\mathrm{p}}-\mathrm{iOM} \\
k_{\mathrm{p}}-\mathrm{iADF}\end{array}$ & $\begin{array}{l}0.0298 \\
0.0318\end{array}$ & $\begin{array}{l}0.0256 \\
0.0282\end{array}$ & $\begin{array}{l}0.0027 \\
0.0030\end{array}$ & $\stackrel{*}{N S}$ \\
\hline$k_{\mathrm{p}}$-iADF-SP & 0.0488 & 0.0303 & 0.0079 & * \\
\hline$k_{\mathrm{c}}-\mathrm{OM}$ & 0.0422 & 0.0442 & 0.0070 & NS \\
\hline
\end{tabular}

NS, not significant.

$* P<0.05$.

$\dagger$ For details of silages and procedures, see Table 1 and pp. 42-44.

different from $k_{\mathrm{p}}$-iADF-SP, but only a very poor correlation between these two fractional passage rates was found $(r 0 \cdot 20)$.

Total clearance rate of OM from the rumen (calculated from the slope of the log decline curve, $r 0.89-0.99: k_{\mathrm{c}}-\mathrm{OM}$ ), which is the sum of disappearance due to passage and due to degradation, did not differ between silages, but was even lower for silage FC than the $k_{\mathrm{p}}$ calculated from the decline in rumen Cr-pool (Table 2).

\section{DISCUSSION}

The lignin content of cell walls increases when a plant matures (Van Soest, 1982), resulting in a decrease in digestibility (Reid et al. 1988). The silages in the present study were grown in the same field and were harvested at different growth stages. The FC silage was harvested at a more mature stage than the SC silage. Lignin content of silage FC was highest, and thus this silage would be expected to have the lowest digestibility.

The DM pool size of the rumen can limit roughage intake in high-producing dairy cows (Mertens, 1987). Because intake and total rumen weights of silage FC were higher than those of silage SC, intake of silage SC at least was not limited by the capacity of the rumen.

The particle size distributions were used to calculate the pool sizes of large and small particles (LP pool and SP pool respectively). The iADF fractions in both pools at different times after feeding were used to calculate the passage rate of SP. The iADF fraction can only leave the rumen by passage, and it was assumed that particles have to be smaller than $1.25 \mathrm{~mm}$ to be able to pass to the omasum.

In most experiments reported in the literature the fractional passage rate of particles from the rumen is calculated from the faecal concentration curve of Cr-NDF. Bosch $e t$ al. $(1988,1992)$ reported a $25-30 \%$ lower $k_{1}$-Co when derived from the faeces than when measured directly in the rumen. The same observation was made in the present experiment, 
except that the differences here were much larger, with fractional rates of $k_{1}$-Co-faeces being 45 to $50 \%$ lower than values for $k_{1}$-Co-rumen (Table 2). For the particulate marker (Cr-NDF) a similar delay to that of the soluble marker is found when measured in the faeces $\left(k_{\mathrm{p}}\right.$-Cr-faeces) compared with that measured directly in the rumen $\left(k_{\mathrm{p}}\right.$-Cr-rumen; Table 2). However, in this case the difference was only $25 \%$. Gasa et al. (1991) measured $\mathrm{Cr}$ concentration curves in the duodenum and in the faeces and found no differences between the two calculated passage rates. However, they did find a lower Co outflow rate when measured in the duodenum compared with that measured directly in the rumen fluid. It seems that measuring marker concentration curves not directly in the rumen, but further down the gut, results in a considerable underestimation of the marker outflow rate from the rumen.

Robinson et al. (1987) and Bosch et al. (1988, 1992) both concluded that even faecal concentration curves of Cr-NDF must overestimate rumen feed particle passage rate as a fraction of total rumen contents because they sometimes even result in a higher passage rate than total rumen clearance rate. The latter is the sum of passage plus digestion and has to be considerably higher than passage rate.

Cr-NDF can be considered to be representative only of particles able to leave the rumen (passing a $1.25 \mathrm{~mm}$ sieve), since $k_{\mathrm{p}}$-Cr-rumen was not significantly different from the fractional passage rate of undegradable material in SP $\left(k_{\mathrm{p}}\right.$-iADF-SP). A significant correlation between $k_{\mathrm{p}}-\mathrm{Cr}$-rumen and $k_{\mathrm{p}}$-iOM was also observed suggesting that, although absolute values cannot be used, differences between silages in rates of passage from the rumen of total iOM can be measured using Cr-NDF as a marker. The significantly higher values for $k_{\mathrm{p}}$-Cr-rumen, $k_{\mathrm{p}}$-iOM and $k_{\mathrm{p}}$-iADF-SP on silage $\mathrm{FC}$ in combination with the higher rumen DM contents show that total DM outflow rate (rumen contents $\times$ passage rate) for this silage is higher than for silage SC. Probably due to this higher outflow rate, feed intake could be higher for FC despite the higher lignin content.

As with iOM, Cr-NDF particles are not degradable in the rumen (Robinson et al. 1987), so no fermentation gases are trapped in these particles. Gas reduces the functional specific gravity of particles and so delays their passage rate (Sutherland, 1987). Tamminga et al. (1989) demonstrated in dairy cows that undegradable material passes from the rumen at a much faster rate than potentially degradable material. The faster rate of passage of smaller particles, even within the SP pool (Bruining \& Bosch, 1992), and the higher iADF:ADF ratio for smaller particles in the present experiment, agree with this.

Because the LP pools decline with time after feeding (Fig. 2), rate of degradation in this pool and/or rate of physical breakdown of these particles to smaller particles does not seem to be the limiting factor in the reduction of total rumen pool size. A decline in the pools of different particle sizes with time after feeding is shown for both silages, except for the pool containing particles with a size between 0.071 and $1.25 \mathrm{~mm}$. The latter fraction seems to be rather constant for at least $8.5 \mathrm{~h}$ after feeding, indicating that during this time the amount of material cleared from this pool is close to the amount entering this pool. This suggests that clearance rate from this pool is the rate-limiting step in the control of rumen DM content, and that particle size reduction as such is not the only limiting factor for rumen capacity. A combination of size reduction and extent of digestion, the latter influencing the functional specific gravity of the particles, seems more likely.

For both silages, although there is a difference in intake and in total rumen content and at least for one silage (SC) rumen content does not limit intake, the rate-limiting step in the control of rumen contents seems to be the disappearance rate of SP $(0.071-1.25 \mathrm{~mm})$. Considering their size, they are small enough to pass to the omasum, but probably their functional specific gravity is still too low. 
The authors gratefully thank Monique van Os, Dorine Groenevelt, Machteld van Maanen, Leen van den Broek and Hugo Wijnands for their contribution as students in this experiment.

\section{REFERENCES}

Bosch, M. W., Janssen, I. M., van Bruchem, J., Boer, H. \& Hof, G. (1988). Digestion of alfalfa and grass silages in sheep. 1. Rates of fermentation in and passage from the reticulorumen. Netherlands Journal of Agricultural Science 36, 175-185.

Bosch, M. W., Lammers-Wienhoven, S. C. W., Bangma, G. A., Boer, H. \& van Adrichem, P. W. M. (1992). Influence of stage of maturity of grass silages on digestion processes in dairy cows. 2. Rumen contents, passage rates, distribution of rumen and faecal particles and mastication activity. Livestock Production Science $\mathbf{3 2}$, 265-281.

Bruining, M. \& Bosch, M. W. (1992). Ruminal passage rate as affected by Cr-NDF particle size. Animal Feed Science and Technology 37, 193-200.

Faichney, G. J. (1986). The kinetics of particulate matter in the rumen. In Control of Digestion and Metabolism in Ruminants. Proceedings of the VIth International Symposium on Rumen Physiology, pp. 173-195 [L. P. Milligan, W. L. Grovum and A. Dobson, editors]. New Jersey: Prentice Hall.

Gasa, J., Holtenius, K., Sutton, J. D., Dhanoa, M. S. \& Napper, D. J. (1991). Rumen fill and digesta kinetics in lactating Friesian cows given two levels of concentrates with two types of grass silage ad lib. British Journal of Nutrition 66, 381-398.

Goering, H. K. \& van Soest, P. J. (1970). Forage Fiber Analyses. Agricultural Handbook no. 379. Washington D.C.: ARS, USDA.

Kennedy, P. M. \& Poppi, D. P. (1984). Critical particle size in sheep and cattle. Techniques in Particle Size Analysis of Feed and Digesta in Ruminants. Canadian Society of Animal Science, Occasional Publication no. 1, p. 170 [P. M. Kennedy, editor]. Edmonton: Canadian Society of Animal Science.

Mertens, D. R. (1987). Predicting intake and digestibility using mathematical models of ruminal function. Journal of Animal Science 64, 1548-1558.

Penning, P. D. \& Johnson, R. H. (1983). The use of internal markers to estimate herbage digestibility and intake. 2. Indigestible acid-detergent fibre. Journal of Agricultural Science, Cambridge 100, $133-138$.

Poppi, D. P., Norton, B. W., Minson, D. J. \& Hendricksen, R. E. (1980). The validity of the critical size theory for particles leaving the rumen. Journal of Agricultural Science, Cambridge 94, 275-280.

Reid, R. L., Jung, G. A. \& Thayne, W. V. (1988). Relationships between nutritive quality and fiber components of cool season and warm season forages: a retrospective study. Journal of Animal Science 66, 1275-1291.

Robinson, P. H., Tamminga, S. \& van Vuuren, A. M. (1987). Influence of declining level of feed intake and varying the proportion of starch in the concentrate on rumen ingesta quantity, composition and kinetics of ingesta turnover in dairy cows. Livestock Production Science 17, 37-62.

SPSS Inc. (1988). SPSS/PC+ Base Manual. Chicago, IL: SPSS Inc.

Sutherland, T. M. (1987). Particle separation in the forestomachs of sheep. In Aspects of Digestive Physiology in Ruminants, pp. 43-73 [A. Dobson, editor]. Ithaca: Cornell University Press.

Tamminga, S., Robinson, P. H., Vogt, M. \& Boer, H. (1989). Rumen ingesta kinetics of cell wall components in dairy cows. Animal Feed Science and Technology 25, 89-98.

Uden, P., Colluci, P. E. \& Van Soest, P. J. (1980). Investigation of chromium, cerium and cobalt as markers in digesta. Rate of passage studies. Journal of the Science of Food and Agriculture 31, 625-632.

Van Soest, P. J. (1982). Nutritional Ecology of the Ruminant. Corvallis, OR: O\&B Books Inc.

Varian (1987). Operation Manual SpectrAA 300/400, Publication no. 85-100697-00. 